\title{
Persepsi Siswa tentang Pembelajaran Online pada Mata Pelajaran Ekonomi di Masa Pandemi Covid-19
}

\author{
Fahimul Amri' ${ }^{1}$, Cahyo Tri Atmojo² \\ ${ }^{12}$ Pendidikan Ekonomi STKIP PGRI Jombang \\ * e-mail: fahimul.amri@gmail.com
}

\begin{abstract}
This study aims to explain economic learning in secondary schools that was carried out online during the Covid-19 pandemic. This study uses a quantitative approach. The data collection method was through the survey by giving questionnaires to respondents. Research respondents are 216 students. Data analysis was carried out descriptively by explaining the frequency, percentage, and mean score of the responses given by the respondents. The results show that in online learning the teacher gives more assignments as well as delivered the subject matter, multi-way interaction between teachers and students has been built, students still have difficulty understanding the subject matter, students consider online learning carries out from the home to be quite boring, students already have facilities ready. No need to come to school, flexibility and time and money are the advantages of online learning. Meanwhile, it is very dependent on the internet network, the availability of internet data packages, and redundant tasks are the weaknesses of online learning. Students want learning activities to be carried out face-to-face and online (blended learning) during the Covid-19 pandemic.
\end{abstract}

Keywords: online learning; readiness; strengths and weaknesses

How to cite : Amri, F., \& Atmojo, C. (2021). Persepsi Siswa tentang Pembelajaran Online pada Mata Pelajaran Ekonomi di Masa PanJdemi Covid-19. Pedagogi: Jurnal Ilmu Pendidikan, 21(2), 62-76. https://doi.org/https://doi.org/10.24036/pedagogi.v21i2.1179

CC 1 Licensees may copy, distribute, display and perform the work an make derivative and remixes based on it only if they
give the author or licensor the credits (attributtion) in the manner specified by these. Licensees may copy, distribute,
display, and perform the work and make derivative works and remixes based on it only for non-commercial purposes

\section{PENDAHULUAN}

Pandemi Coronavirus Disease-2019 (Covid-19) yang melanda seluruh dunia telah memberikan perubahan yang frontal dalam bidang pendidikan, termasuk pendidikan di Indonesia. Pelaksanaan pendidikan dan pembelajaran yang awalnya dilaksanakan secara tatap muka berubah secara sangat cepat menjadi pembelajaran yang dilaksanakan secara online (daring) akibat adanya pandemi Covid-19. Di semua negara yang terdampak dari adanya virus Corana memaksa semua sekolah untuk merubah pembelajaran tatap muka menjadi pembelajaran secara online untuk mencegah penyebaran virus agar tidak menjadi semakin meluas (Murphy, 2020). Termasuk di Indonesia, kebijakan untuk mencegah agar virus tidak menjadi semakin meluas memaksa pemerintah mengeluarkan kebijakan tentang menjaga jarak secara fisik dan menjaga jarak secara social (social distancing) dalam pembelajaran. Adanya kebijakan tersebut, memaksa sekolah untuk melaksanakan pembelajaran online (daring) dari rumah kepada semua siswanya.

Sebelum adanya guncangan pandemi Covid-19 yang melanda seluruh dunia yang mengubah pembelajaran tatap muka menjadi pembelajaran online, pembahasan tentang pembelajaran online telah dibahas (misalnya oleh Anderson, 2008; Balula \& Moreira, 2014; Cigdem \& Yildirim, 2014; Harasim, 2012; Nord, 2011). Bahkan penelitian tentang pembelajaran online telah banyak 
dilakukan di berbagai jenjang pendidikan, misalnya penelitian yang dilakukan tentang kinerja dan kepuasan mahasiswa dalam mengikut pembelajaran online di perguruan tinggi (Alqurashi, 2018; Wei \& Chou, 2020), penelitian tentang kesiapan siswa dalam pembelajaran online di perguruan tinggi (Joosten \& Cusatis, 2020), dan pembelajaran online di tingkat sekolah dasar dan menengah (Barbour, 2017; Borup \& Kennedy, 2017; Dewstow \& Wright, 2005).

Pembelajaran online merupakan pembelajaran yang memanfaatkan teknologi internet untuk menyampaikan konten pembelajaran yang dapat berupa teks, video, audio dan lain-lain (Nord, 2011). Hal yang sama juga diungkapkan bahwa pembelajaran online merupakan pembelajaran yang menggunakan sarana internet untuk berinteraksi antara konten pembelajaran, guru dan siswa, serta sebagai sebagai sarana sharing materi pelajaran (Ally, 2008; Fahy, 2008). Senada dengan pengertian tersebut pembelajaran online merupakan pembelajaran yang dilaksanakan tanpa adanya kontak fisik secara secara langsung dengan memanfaatkan jaringan internet dengan aksesibilitas, konektivitas, dan fleksibilitas sebagai sarana penghubung antara guru dan siswa, sehingga terjadi interaksi antara guru dan siswa (Moore et al., 2011; Pratiwi, 2020).

Pelaksanaan pembelajaran online sebelum masa pandemi Covid-19 maupun saat masa pandemi telah menunjukkan kelebihan dalam pelaksanaanya maupun telah memberikan dampak yang positif bagi siswa dalam belajar. Pelaksanaan pembelajaran online dapat membuat siswa merasa nyaman dalam belajar sehingga mempunyai kecenderungan tampil lebih baik dalam proses pembelajaran (Hurlbut, 2018), memiliki dampak positif bagi keterlibatan siswa pada pembelajaran (Chen et al., 2010), memberikan dampak positif pada kesiapan belajar siswa selama pembelajaran online (Wei \& Chou, 2020), mampu mengurangi kecemasan dan membuat siswa lebih mandiri dalam belajar (Kongrith \& Maddux, 2005), kesiapan pembelajaran online dapat meningkatkan kinerja akademik mahasiswa (Joosten \& Cusatis, 2020), dan dengan pembelajaran online mampu memberikan jangkauan pendidikan yang lebih luas (Mahnun, 2018; Moore et al., 2011).

Selanjutnya pembelajaran online juga memiliki kelebihan lainnya yaitu dapat mempermudah penyampaian dan penyimpanan materi pembelajaran (Mahnun, 2018; Surani et al., 2020), dan dapat menghemat biaya termasuk menghemat biaya transportasi (Hamid, 2002; Handayani, 2020; Pratiwi, 2020; Purwanto et al., 2020; Putri et al., 2020; Ramanta \& Widayanti, 2020; Setyorini, 2020). Kelebihan lainnya menunjukkan pembelajaran yang dilaksanakan secara online mempunyai fleksibilitas waktu dan tempat (Anderson \& Dron, 2011; Anugrahana, 2020; Firman \& Rahayu, 2020; Hamid, 2002; Handayani, 2020; Kirin et al., 2021; Nugroho, 2020; Ulfia, 2020). Hal yang sama juga diungkapkan bahwa pembelajaran online dapat memudahkan dan memiliki fleksibilitas waktu dan tidak terikat dengan lokasi belajar bagi guru dan siswa terutama berkaitan dengan penentuan jadwal belajar mengajar secara online (Gunawan et al., 2020), dan bebas berpartisipasi dalam belajar, fleksibel, dan dapat dilaksanakan dimana saja dan kapan saja (Wongjamnong et al., 2021).

Namun, pelaksanaan pembelajaran online yang diikuti oleh siswa juga tidak terlepas dari adanya hambatan atau kelemahan yang menyertai. Kelemahan pembelajaran yang dilaksanakan secara online terlihat dari adanya kebosanan bagi siswa selama mengikuti pembelajaran online (Anugrahana, 2020; Jannah et al., 2020; Noviati, 2020; Pujiasih, 2020; Purwanto et al., 2020; Ramanta \& Widayanti, 2020). Selajutnya hambatan atau kelemahanan yang lain adalah guru selama melaksanakan pembelajaran online lebih banyak memberikan tugas kepada siswa yang terkadang tidak diberikan penjelasan terlebih dahulu (Noviati, 2020; Pujiasih, 2020; Ramanta \& Widayanti, 2020; Surani et al., 2020). Lebih lanjut kegiatan pembelajaran online yang dilaksanakan oleh guru dalam bentuk pemberian tugas, diskusi, dan pemberian kuis (Surani et al., 2020).

Hambatan atau permasalahan lain yang menjadi kelemahan dalam pembelajaran yang dilaksanakan secara online adalah paket data yang terbatas atau kuota data internet yang mahal dan cepat habis, serta jaringan internet yang tidak memadai dan tidak stabil atau sinyal internet yang lambat dan sulit (Anugrahana, 2020; Bustomi, 2020; Engko \& Usmany, 2020; Firman \& Rahayu, 2020; Gayatri et al., 2021; Handayani, 2020; Jannah et al., 2020; Kirin et al., 2021; Ma et al., 2021; Mustopa \& Hidayat, 2020; Noviati, 2020; Pujiasih, 2020; Ramanta \& Widayanti, 2020; 
Rohmanu et al., 2020; Sadikin \& Hamidah, 2020; Surani et al., 2020; Ulfia, 2020). Hambatan dalam jaringan internet dan keterbatasan kuota data internet dapat menyebabkan keterlambatan dalam mengakses informasi pembelajaran, menjangkau konten pembelajaran, dan mengumpulkan tugas (Engko \& Usmany, 2020; Firman \& Rahayu, 2020; Jannah et al., 2020; Setiaji \& Dinata, 2020; Ulfia, 2020). Hal yang sama juga diungkapkan bahwa pembelajaran yang dilaksanakan secara online membutuhkan jaringan internet yang memadai dan membutuhkan banyak biaya (Pratiwi, 2020).

Berdasarkan temuan beberapa penelitian tersebut, nampakya berkaitan dengan jaringan internet dihampir semua penelitian yang membahas tentang pembelajaran online, jaringan internet dapat menjadi masalah yang besar bagi efektivitas pembelajaran yang dilaksanakan secara online jika terjadi gangguan. Apalagi bagi siswa yang tinggal di daerah yang jaringan internetnya masih belum memadai. Disamping itu masalah kuota data atau paket data internet untuk mengakses pembelajaran online juga menjadi masalah yang besar bagi siswa, ketika siswa mengikuti pembelajaran online yang memanfaatkan jaringan Wifi yang ada di tempat tertentu yang diperoleh secara gratis tidak menjadi masalah, tetapi ketika kuota data internet harus dibeli dengan harga yang relatif tidak murah untuk mendapatkan paket data internet dan atau paket data internet yang tidak mencukupi, hal ini dapat menjadi hambatan bagi pelaksanaan pembelajaran online. Apalagi ketika guru menerapkan pembelajaran online dengan menggunakan aplikasi yang dapat lebih cepat menghabiskan kuota data internet.

Selain itu pembelajaran yang dilaksanakan secara online membuat interaksi dan komunikasi yang terjadi diantara dosen dengan mahasiswa dan antar mahasiswa kurang berjalan dengan baik (Mustopa \& Hidayat, 2020; Noviati, 2020; Nuriansyah, 2020; Pratiwi, 2020; Purwanto et al., 2020; Putri et al., 2020; Rohmanu et al., 2020; Setyorini, 2020), bahkan dikatakan interaksi dan komunikasi dalam pembelajaran online kurang lancar dan cenderung satu arah (Surani et al., 2020). Hal yang sama juga ditemukan bahwa pembelajaran online mengurangi interaksi secara langsung antara siswa dengan siswa lainnya dalam kelas (Rabe-Hemp et al., 2009). Temuan dari beberapa peneliti tersebut nampaknya berbeda yang ditunjukkan bahwa pembelajaran online dapat meningkatkan dan mempermudah interaksi pembelajaran dengan lancar tanpa dibatasi waktu dan tempat (Mahnun, 2018).

Selanjutnya pembelajaran yang dilaksanakan secara online selama ini membuat siswa merasa kesulitan untuk berkonsentrasi, partisipasi yang masih rendah selama mengikuti pembelajaran, dan kesulitan memahami materi pelajaran yang diajarkan oleh guru. Kesulitan tersebut dapat terjadi karena siswa sudah terbiasa dengan pembelajaran yang dilaksanakan secara tatap muka (Jannah et al., 2020; Pujiasih, 2020; Ramanta \& Widayanti, 2020; Surani et al., 2020; Ulfia, 2020). Hal ini tentunya menarik untuk diperhatikan bahwa pembelajaran yang dilaksanakan secara langsung seperti pembelajaran tatap muka lebih kondusif dari pada pembelajaran yang dilaksanakan dengan memanfaatkan teknologi yang berbasis internet (Figlio et al., 2013). Hal yang sama juga ditunjukkan bahwa pembelajaran yang dilaksanakan secara tatap muka masih dianggap lebih baik jika dibandingkan dengan pembelajaran yang dilaksanakan secara online, karena pembelajaran tatap muka lebih mudah memahami materi pelajaran dan lebih mudah dalam melakukan interaksi antara guru dan siswa (Kirin et al., 2021). Namun pendapat yang berbeda menunjukkan pembelajaran yang dilaksanakan secara online mempunyai hasil yang tidak jauh berbeda dengan hasil pembelajaran yang dilakukan dengan tatap muka (Kharisma et al., 2020).

Berdasarkan penjelasan tersebut, pembelajaran online yang dilaksanakan selama masa pandemi Covid-19 menunjukkan beragam temuan, termasuk menunjukkan kesiapan siswa, kelebihan, maupun kelemahan yang dapat menghambat proses pelaksanaan pembelajaran. Oleh karena itu dalam penelitian ini berupaya mengungkapkan persepsi tentang pembelajaran online yang diterapkan selama pandemi Covid-19 dalam pembelajaran ekonomi, baik dari kesiapan siswa, kelebihan maupun kelemahan yang ada, maupun keinginan siswa dalam mengikuti pembelajaran di masa pandemi Covid-19, sehingga dapat diperoleh gambaran dan penjelasan tentang pembelajaran online pada mata pelajaran ekonomi di masa pandemi. 


\section{METODE}

Penelitian ini menggunakan pendekatan kuantitatif dengan analisis data dilakukan secara deskriptif. Respoden dalam penelitian ini adalah siswa SMA dan MA yang telah mengikuti pembelajaran ekonomi yang dilaksanakan secara online (daring) yang ada di kabupaten Jombang. Teknik pengambilan responden berdasarkan metode purposive sampling yaitu pengambilan responden berdasarkan pada pencapaian tujuan penelitian dan berdasarkan pertimbangan tertentu. Respoden dalam penelitian ini berjumlah 216 siswa (67 laki-laki, 149 perempuan). Metode pengumpulan data dilakukan melalui survey kepada siswa dengan memberikan angket secara online (google form). Instrumen angket mempunyai beberapa item pertanyaan yang memberikan kesempatan kepada responden untuk memilih jawaban lebih dari satu jawaban.

Analisis data secara deskriptif dilakukan dengan menjelaskan frequensi dan persentase dari temuan penelitian. Selain itu analisis deskriptif juga dilakukan dalam bentuk kategori yang dibuat skala untuk menjelaskan skor rata-rata jawaban responden atas beberapa item pertanyaan yang ada dalam angket. Skala kategori dihitung dari skor tertinggi dikurangi skor terendah di bagi 5 kategori jawaban $((5-1) / 5)$, sehingga diperoleh rentang skala untuk setiap kategori sebesar 0.80 , yaitu sangat tidak baik $(1 \geq x \leq 1.80)$, tidak baik $(1.81 \geq x \leq 2.60)$, cukup $(2.61 \geq x \leq 3.40)$, baik $(2.41 \geq x \leq 4.20)$, dan sangat baik $(4.21 \geq x \leq 5)$ (Amri et al., 2020).

\section{TEMUAN DAN PEMBAHASAN}

\section{Analisis Data}

Berdasarkan hasil survey yang telah dilakukan dengan melalui angket yang telah diisi oleh responden berkaitan dengan pembelajaran online yang diikuti siswa, menunjukkan data yang dapat dijelaskan sebagai berikut:

\section{Jarak Rumah dengan Sekolah}

Berdasarkan data yang diperoleh dari survey menunjukkan jarak rumah siswa dengan sekolah ditampilkan dalam tabel berikut:

Tabel 1. Jarak Sekolah dengan Rumah

\begin{tabular}{lcc}
\hline \multicolumn{1}{c}{ Jarak Rumah dengan Sekolah } & Frequensi & Persentase (\%) \\
\hline$\pm<5 \mathrm{~km}$ & 70 & 32.4 \\
\hline$\pm \geq 5 \mathrm{~km}$ & 146 & 67.6 \\
\hline
\end{tabular}

Berdasarkan tabel 1, menunjukkan bahwa jumlah siswa yang rumahnya berjarak kurang dari lima kilometer berjumlah 70 siswa $(32.4 \%)$ dan siswa yang rumahnya berjarak lima kilo meter atau lebih berjumlah 146 siswa (67.6\%). Berdasarkan data tersebut menunjukkan responden penelitian lebih banyak yang rumahnya berjarak lima kilometer atau lebih dengan sekolah.

2. Kegiatan Pembelajaran yang diterapkan dalam Pembelajaran Online

Kegiatan pembelajaran yang diterapkan oleh guru dalam pembelajaran ekonomi yang dilaksanakan secara online berdasarkan persepsi siswa dapat ditunjukkan dalam tabel berikut:

Tabel 2. Kegiatan Pembelajaran Online

\begin{tabular}{lcc}
\hline \multicolumn{1}{c}{ Kegiatan Pembelajaran Online } & Frequensi & Persentase (\%) \\
\hline Memberikan tugas makalah/studi kasus & 59 & 12.37 \\
\hline Memberikan tugas proyek/ produk & 51 & 10.69 \\
\hline Kuis dan mengerjakan soal & 187 & 39.20 \\
\hline Kegiatan diskusi & 78 & 16.35 \\
\hline Penyampaian materi & 102 & 21.38 \\
\hline
\end{tabular}

Berdasarkan Tabel 2, bahwa kegiatan pembelajaran ekonomi yang diterapkan oleh guru dalam pembelajaran online berdasarkan persepsi siswa (untuk pertanyaan ini siswa boleh 
memberikan lebih dari satu jawaban) menunjukkan sebanyak 59 jawaban (12.37\%) dari 216 siswa yang mengungkapkan bahwa guru selama melaksanakan pembelajaran online memberikan tugas dalam bentuk makalah atau studi kasus. Sebanyak 51 jawaban (10.69\%) dari 216 siswa mengungkapkan bahwa guru selama pembelajaran online memberikan tugas yang berbasis proyek atau tugas produk. Sebanyak 187 jawaban (39.20\%) dari 216 siswa mengungkapkan guru dalam pembelajaran online memberikan tugas dalam bentuk kuis dan mengerjakan soal. Sebanyak 78 jawaban (16.35\%) dari 216 siswa yang mengungkapkan bahwa guru dalam pembelajaran online melaksanakan kegiatan diskusi kelas, dan sebanyak 102 jawaban $(21.38 \%)$ dari 216 siswa yang mengungkapkan bahwa dalam pembelajaran online guru penyampaian materi pelajaran. Berdasarkan persepsi siswa tentang pembelajaran ekonomi yang dilaksanakan selama pembelajaran online menunjukkan bahwa pemberian kuis atau tugas mengerjakan soal menjadi kegiatan pembelajaran yang sering dilakukan oleh guru selama pembelajaran online.

3. Interaksi selama proses pembelajaran online

Interaksi yang terjadi selama pembelajaran ekonomi yang dilaksanakan secara online menurut persepsi siswa dapat ditampilkan dalam tabel berikut.

Tabel 3. Interaksi Guru dan Siswa dalam Pembelajaran Online

\begin{tabular}{lll}
\hline \multicolumn{1}{c}{$\begin{array}{c}\text { Interaksi yang Terjadi Selama Proses } \\
\text { Pembelajaran Online }\end{array}$} & Frequensi & Persentase (\%) \\
\hline Guru lebih dominan & 67 & 31 \\
\hline Siswa lebih dominan & 20 & 9.3 \\
\hline Tidak ada yang lebih dominan/multi arah & 129 & 59.7 \\
\hline
\end{tabular}

Berdasarkan tabel 3, tentang interaksi antara guru dan siswa yang terjadi selama proses pembelajaran online, menunjukkan siswa yang berpendapat bahwa guru lebih dominan dalam interaksi dengan siswa selama proses pembelajaran online sebanyak 67 siswa (31\%). Siswa yang berpendapat bahwa siswa yang lebih dominan dalam proses pembelajaran online hanya 20 siswa (9.3\%). Sedangkan siswa yang bependapat bahwa pembelajaran online tidak ada yang lebih dominan atau terjadi interaksi multiarah antara guru dan siswa sebanyak 129 siswa (59.7\%). Berdasarkan data yang ditampilkan dalam tabel tersebut menunjukkan interaksi selama proses pembelajaran online lebih banyak interaksi yang multi arah antara guru dengan siswa, dan siswa dengan siswa lainnya.

4. Kemampuan memahami materi pelajaran dalam pembelajaran online

Selama proses pembelajaran online, kemampuan siswa dalam memahami materi pelajaran ekonomi yang disampaikan oleh guru berdasarkan persepsi siswa dapat ditampilkan dalam tabel berikut:

Tabel 4. Kemampuan Memahami Materi Pelajaran dalam Pembelajaran Online

\begin{tabular}{|c|c|c|c|}
\hline $\begin{array}{c}\text { Kemampuan Memahami } \\
\text { Materi Pelajaran }\end{array}$ & Frequensi & Persentase $(\%)$ & Rata-rata \\
\hline Sangat sulit & 16 & 7.4 & \multirow{5}{*}{2.58} \\
\hline Sulit & 95 & 44 & \\
\hline Biasa saja & 69 & 31.9 & \\
\hline Mudah & 35 & 16.2 & \\
\hline Sangat mudah & 1 & 0.5 & \\
\hline
\end{tabular}

Berdasarkan Tabel 4, menunjukkan selama mengikuti pembelajaran online siswa yang menganggap bahwa dengan pembelajaran online sangat sulit memahami materi pelajaran sebanyak 16 siswa (7.4\%). Siswa yang menganggap bahwa selama mengikuti pembelajaran online sulit untuk memahami pelajaran sebanyak 95 siswa (44\%). Siswa yang menganggap bahwa selama mengikuti pembelajaran online biasa saja dalam memahami pelajaran sebanyak 69 siswa (31.9\%). Siswa yang menganggap bahwa selama mengikuti pembelajaran online mudah untuk 
memahami pelajaran sebanyak 35 siswa (16.2\%). Siswa yang menganggap bahwa selama mengikuti pembelajaran online sangat mudah untuk memahami pelajaran sebanyak 1 siswa $(0.5 \%)$. Berdasarkan skor rata-rata sebesar 2.58 menunjukkan bahwa kemampuan siswa dalam memahami materi pelajaran ekonomi yang diajarkan oleh guru selama pembelajaran online dalam kategori tidak baik. Dengan demikian dapat dimaknai bahwa selama mengikuti pembelajaran online banyak siswa yang mengalami kesulitan untuk memahami materi pelajaran.

5. Pendapat siswa tentang pembelajaran online yang dilaksanakan dari rumah

Selama mengikuti pembelajaran online, siswa mempunyai persepsi tentang pembelajaran online yang dilaksanakan dari rumah yang ditampilkan dalam tabel berikut:

Tabel 5. Persepsi Siswa tentang Pembelajaran Online yang Dilaksanakan dari Rumah

\begin{tabular}{lccc}
\hline $\begin{array}{l}\text { Pembelajaran Online yang } \\
\text { Dilaksanakan dari Rumah }\end{array}$ & Frequensi & Persentase (\%) & Rata-rata \\
\hline Sangat membosankan & 18 & 8.2 & \\
\hline Membosankan & 63 & 29.2 & \multirow{2}{*}{2.74} \\
\hline Biasa saja & 98 & 45.4 & \\
\hline Menyenangkan & 31 & 14.4 & 2.8 \\
\hline Sangat menyenangkan & 6 & & \\
\hline
\end{tabular}

Berdasarkan Tabel 5, menunjukkan siswa yang menganggap bahwa pembelajaran online yang dilaksanakan dari rumah sangat membosankan sebanyak 18 siswa (8.2\%). Siswa yang menganggap pembelajaran online yang dilaksanakan dari rumah membosankan sebanyak 63 siswa (29.2\%). Siswa yang menganggap pembelajaran online yang dilaksanakan dari rumah biasa saja sebanyak 98 siswa (45.4\%). Siswa yang menganggap pembelajaran online yang dilaksanakan dari rumah menyenangkan sebanyak 31 siswa (14.4\%). Siswa yang menganggap bahwa pembelajaran online yang dilaksanakan dari rumah sangat menyenangkan sebanyak 6 siswa (2.8\%). Berdasarkan skor rata-rata sebesar 2.74 menunjukkan bahwa pembelajaran online yang dilaksanakan dari rumah dalam kategori cukup. Dengan demikian dapat dimaknai bahwa pembelajaran online yang diikuti oleh siswa dari rumah cukup membosankan bagi mereka.

6. Kesiapan fasilitas untuk mengikuti pembelajaran online

Fasilitas seperti handphone (smartphone), jaringan internet, dan ketersediaan kuota internet (paket data) sangat diperlukan untuk mengikuti pembelajaran online. Berdasarkan persepsi siswa tentang kesiapan fasilitas yang dimiliki untuk mengikuti pembelajaran online dapat ditampilkan dalam tabel beribut

Tabel 6. Kesiapan Fasilitas yang Dimiliki/Tersedia untuk Mengikuti Pembelajaran Online

\begin{tabular}{|c|c|c|c|}
\hline Kesiapan Fasilitas yang Dimiliki/Tersedia & Frequensi & Persentase (\%) & Rata-rata \\
\hline $\begin{array}{l}\text { Tidak siap (mempunyai HP, jaringan } \\
\text { internet lambat/tidak stabil, kuota data } \\
\text { sering tidak punya/sering tidak mencukupi) }\end{array}$ & 11 & 5.1 & \\
\hline $\begin{array}{l}\text { Kurang siap (mempunyai HP, jaringan } \\
\text { internet stabil/cepat, kuota data sering tidak } \\
\text { punya/sering tidak mencukupi) }\end{array}$ & 35 & 16.2 & \\
\hline $\begin{array}{l}\text { Cukup siap (mempunyai HP, jaringan } \\
\text { internet stabil/cepat, kuota terkadang } \\
\text { mencukupi }\end{array}$ & 59 & 27.3 & 3.59 \\
\hline $\begin{array}{l}\text { Siap (mempunyai HP, jaringan internet } \\
\text { cepat/stabil, kuota sering mencukupi }\end{array}$ & 36 & 16.7 & \\
\hline $\begin{array}{l}\text { Sangat siap (mempunyai } \mathrm{HP}, \text { jaringan } \\
\text { internet cepat/stabil dan kuota selalu } \\
\text { mencukupi) }\end{array}$ & 75 & 34.7 & \\
\hline
\end{tabular}


Berdasarkan Tabel 6, menunjukkan bahwa selama mengikuti pembelajaran online, kesiapan siswa dalam fasilitas yang dimiliki/tersedia untuk mengikuti pembelajaran secara online yang menyatakan tidak siap sebanyak 11 siswa (5.1\%). Siswa yang menyatakan kurang siap tentang fasilitas yang dimiliki/tersedia untuk mengikuti pembelajaran online sebayak 35 siswa (16.2\%). Siswa yang menyatakan cukup siap tentang fasilitas yang dimiliki/tersedia untuk mengikuti pembelajaran online sebanyak 59 siswa (27.3\%). Siswa yang menyatakan memiliki/tersedia fasilitas yang siap digunakan untuk mengikuti pembelajaran online sebanyak 36 siswa (16.2\%). Siswa yang menyatakan mempunyai fasilitas yang sangat siap untuk mengikuti pembelajaran online sebanyak 75 siswa (34.7\%). Berdasarkan skor rata-rata sebesar 3.59 menunjukkan bahwa siswa mempunyai kesiapan fasilitas dalam kategori baik selama mengikuti pembelajaran online. Dengan demikian dapat dimaknai bahwa siswa mempunyai kesiapan yang baik terhadap fasilitas yang dimiliki/tersedia selama mengikuti pembelajaran online.

7. Keunggulan atau kelebihan pembelajaran online

Keunggulan atau kelebihan pembelajaran yang dilaksanakan secara online berdasarkan persepsi siswa dapat ditampilkan dalam tabel berikut:

Tabel 7. Kelebihan Pembelajaran Online

\begin{tabular}{lcc}
\hline \multicolumn{1}{c}{ Kelebihan Pembelajaran Online } & Frequensi & Persentase (\%) \\
\hline Tidak perlu datang ke sekolah & 160 & 44.20 \\
\hline Fleksibel & 94 & 25.97 \\
\hline Hemat waktu dan biaya & 72 & 19.89 \\
\hline Mudah memahami & 7 & 1.93 \\
\hline Lebih aktif belajar & 29 & 8.01 \\
\hline
\end{tabular}

Berdasarkan Tabel 7. menunjukkan persepsi siswa (untuk pertanyaan ini siswa dapat memberikan jawaban lebih dari satu) bahwa pembelajaran yang dilaksanakan secara online mempunyai keunggulan atau kelebihan. Sebanyak 160 jawaban (44.20\%) dari 216 siswa yang menyebutkan bahwa pembelajaran yang dilaksanakan secara online menpunyai keunggulan atau kelebihan yaitu tidak perlu datang ke sekolah. Sebanyak 94 jawaban (25.97\%) dari 216 siswa yang menyebutkan bahwa pembelajaran yang dilaksanakan secara online dapat diikuti secara fleksibel. Sebanyak 72 jawaban (19.89\%) dari 216 siswa yang menyebutkan bahwa pelaksananaan pembelajaran online dapat menghemat waktu dan biaya. Sebanyak 7 jawaban (1.93\%) dari 216 siswa yang menyebutkan bahwa pembelajaran yang dilaksanakan secara online mudah untuk memahami materi pelajaran. Sebanyak 29 jawaban (8.01\%) dari 216 siswa yang menyebutkan bahwa pembelajaran yang dilaksanakan secara online dapat membuat lebih aktif dalam belajar. Berdasarkan banyaknya jawaban dari responden terhadap kelebihan pembelajaran online, maka dapat dikatakan bahwa tidak perlu datang ke sekolah, pelaksanaannya fleksibel, serta hemat waktu dan biaya merupakan kelebihan dari pembelajaran online yang sering diperoleh siswa.

\section{Kelemahan pembelajaran online}

Pembelajaran yang dilaksanakan secara online juga mempunyai kelemahan yang dapat menjadi hambatan untuk mencapai efektivitas pembelajaran. Kelemahan dalam pembelajaran online berdasarkan persepsi siswa dapat ditampilkan dalam tabel berikut

Tabel 8. Kelemahan Pembelajaran Online

\begin{tabular}{lcc}
\hline \multicolumn{1}{c}{ Kelemahan Pembelajaran Online } & Frequensi & Persentase (\%) \\
\hline Sangat bergantung jaringan internet & 165 & 28.90 \\
\hline Ketersediaan kuota/paket data internet & 175 & 30.65 \\
\hline Tugas yang berlebihan & 152 & 26.62 \\
\hline Jadwal yang berubah-ubah & 79 & 13.83 \\
\hline
\end{tabular}

Berdasarkan Tabel 8, menunjukkan bahwa pembelajaran yang dilaksanakan secara online mempunyai kelemahan. Ada beberapa kelemahan dari pembelajaran yang dilaksanakan secara 
online yang dapat menjadi masalah bagi siswa. Berdasarkan persepsi siswa (dalam pertanyaan ini siswa dapat memberikan lebih dari satu jawaban) menunjukkan bahwa sebanyak 165 jawaban $(28.90 \%)$ dari 216 siswa yang berpendapat pembelajaran online sangat bergantung pada jaringan internet. Sebanyak 175 jawaban (30.65\%) dari 216 siswa yang berpendapat bahwa pembelajaran online sangat bergantung ketersediaan kuota internet. Sebanyak 152 jawaban (26.62\%) dari 216 siswa yang berpendapat bahwa guru selama melaksanakan pembelajaran online lebih banyak memberikan tugas kepada siswa. Sebanyak 79 jawaban (18.83\%) dari 216 siswa yang berpendapat bahwa pembelajaran online dilaksanakan tidak tepat waktu atau jadwalnya yang berubah-ubah. Berdasarkan persepsi siswa tersebut menunjukkan bahwa jaringan internet, kuota internet (paket data internet), dan banyaknya tugas pelajaran yang diberikan oleh guru menjadi kelemahan yang dapat menjadi masalah yang sering ditemui dalam pembelajaran yang dilaksanakan secara online.

9. Pelaksanaan Pembelajaran yang diinginkan Siswa selama Pandemi

Akibat adanya pandemi Covid-19, memaksa pembelajaran dari tatap muka menjadi pembelajaran yang harus dilaksanakan secara online. Berdasarkan hal tersebut, persepsi siswa tentang pelaksanaan pembelajaran yang diinginkan ditampilkan dalam tabel berikut

Tabel 9. Pelaksanaan Pembelajaran yang Diinginkan Siswa

\begin{tabular}{lccc}
\hline $\begin{array}{c}\text { Pelaksanaan Pembelajaran yang } \\
\text { Diinginkan Siswa }\end{array}$ & Frequensi & Persentase (\%) \\
\hline Setuju $100 \%$ dilaksanakan secara online & 30 & 13.9 \\
\hline $\begin{array}{l}\text { Setuju } \\
\text { muka }\end{array}$ & $80 \%$ dilaksanakan secara tatap & 80 & 37 \\
\hline $\begin{array}{l}\text { Setuju pembelajaran campuran } \\
\text { (dilaksanakan dengan cara tatap muka di } \\
\text { sekolah dan dilaksanakan secara online) }\end{array}$ & 106 & 49.1 \\
\hline
\end{tabular}

Berdasarkan Tabel 9, menunjukkan sebanyak 30 siswa (13.9\%) yang setuju terhadap pembelajaran yang dilaksanakan secara online secara penuh. Sebanyak 80 siswa (37\%) yang berpendapat setuju terhadap pembelajaran yang dilaksanakan secara tatap muka di sekolah secara penuh. Sebanyak 106 siswa (49.1\%) yang berpendapat setuju terhadap pembelajaran yang dilaksanakan secara campuran (blended learning). Berdasarkan tabel tersebut dapat dimaknai bahwa dalam masa pademi Covid-19 seperti ini banyak siswa yang menginginkan pembelajaran dapat dilaksanakan secara campuran yaitu menggabungkan antara pembelajaran yang dilaksanakan secara online dengan pembelajaran yang dilaksanakan secara tatap muka. Meskipun demikian, masih banyak siswa yang menginginkan agar selama pandemi, pembelajaran dapat dilaksanakan secara tatap muka di sekolah.

\section{Pembahasan}

Pembelajaran yang dilaksanakan secara online selama pandemi Covid-19 menjadi satusatunya jalan yang harus dilakukan agar pembelajaran di sekolah dapat terus berlangsung. Termasuk pada pembelajaran ekonomi di sekolah menengah juga melaksanakan pembelajaran secara online dengan memanfaatkan sarana internet untuk dapat mengakses pembelajaran. Selama pembelajaran online dalam mata pelajaran ekonomi, berbagai bentuk kegiatan pembelajaran diterapkan oleh guru agar pembelajaran dapat berjalan dengan baik dan kondusif, sehingga efektivitas pembelajaran dapat dicapai. Dari berbagai kegiatan pembelajaran oleh guru ekonomi selama melaksanakan pembelajaran secara online yang sering diterapkan adalah memberikan kuis dan tugas mengerjakan soal disusul dengan penyampaian materi. Disamping itu guru juga memberikan tugas dalam bentuk yang lain kepada siswa. diskusi kelas juga diterapkan oleh guru selama pembelajaran online.

Hasil penelitian ini sejalan dengan pendapat sebelumnya mengungkapkan bahwa selama pembelajaran online guru lebih banyak memberikan tugas kepada siswa (Noviati, 2020; Pujiasih, 2020; Ramanta \& Widayanti, 2020; Ulfia, 2020), bahkan lebih lanjut ada yang menyebutkan 
selama pembelajaran online pendidik lebih banyak memberikan tugas tanpa disertai dengan penjelasan terlebih dahulu kepada siswa, sehingga siswa menjadi kurang memahami materi pelajaran (Gayatri et al., 2021; Surani et al., 2020). Namun berdasarkan hasil penelitian ini yang menunjukkan cukup banyaknya siswa yang memberikan jawaban tentang kegiatan pembelajaran yang dilaksanakan secara online dalam bentuk penyampaian materi pelajaran, menunjukkan bahwa sebagian guru ekonomi sebelum memberikan berbagai bentuk tugas seperti mengerjakan soal maupun tugas lain, guru terlebih dahulu memberikan penjelasan terkait dengan materi yang sedang dipelajari siswa, meskipun ada guru yang secara langsung memberikan tugas tanpa disertai penjelasan terlebih dahulu.

Selanjutnya hasil penelitian ini juga mengungkapkan bahwa pembelajaran yang dilaksanakan secara online juga mampu menciptakan interaksi dan komunikasi yang baik diantara guru dan siswa. Berdasarkan data di tabel 3. menunjukkan interaksi dan komunikasi yang terjadi di dalam proses pembelajaran online lebih banyak di dominasi oleh interaksi dan komunikasi yang multi arah antara guru dengan siswa, meskipun di dalam proses pembelajaran online juga masih ditemukan guru yang lebih dominan dalam proses pembelajaran. Berdasarkan hasil ini menunjukkan kesesuaian dengan temuan sebelumnya yang menyebutkan pembelajaran online masih tetap mampu menghadirkan interaksi dan komunikasi yang baik antara guru dengan siswa atau antar siswa dalam pembelajaran (Kharisma et al., 2020; Mahnun, 2018; Markova et al., 2017; Moore et al., 2011; Pratiwi, 2020). Namun hasil penelitian ini sedikit berbeda dengan temuan yang menyebutkan bahwa pembelajaran online dapat menyebabkan berkurangnya interaksi dan komunikasi yang terjadi antara dosen dengan mahasiswa bila dibandingkan dengan perkuliahan tatap muka (Handayani, 2020; Mustopa \& Hidayat, 2020; Nuriansyah, 2020; Purwanto et al., 2020; Putri et al., 2020). Selain itu hasil penelitian ini juga berbeda dengan penelitian sebelumnya yang mengungkapkan bahwa pembelajaran online yang terjadi selama ini belum mampu membangun dengan baik interaksi dan komunikasi secara virtual diantara dosen dengan mahasiswa (Rohmanu et al., 2020).

Hasil penelitian ini juga mengungkapkan bahwa selama mengikuti pembelajaran online, lebih banyak siswa yang mengalami kesulitan untuk memahami materi pelajaran. Berdasarkan hasil tersebut, maka hasil penelitian ini sesuai dengan penelitian sebelumnya yang mengungkapkan bahwa siswa mengalami kesulitan untuk memahami materi pelajaran selama mengikuti pembelajaran online (Pujiasih, 2020; Ramanta \& Widayanti, 2020; Surani et al., 2020; Ulfia, 2020). Hasil penelitian ini juga mendukung bahwa siswa belum terbiasa mengikuti pembelajaran online, sehingga mengalami kesulitan untuk memahami materi pelajaran yang diajarkan oleh guru (Jannah et al., 2020). Dalam konteks ini siswa lebih mudah untuk memahami mata pelajaran yang diajarkan oleh guru melalui pembelajaran tatap muka dari pada pembelajaran yang dilaksanakan secara online (Kirin et al., 2021).

Selajutnya dalam penelitian ini mampu menunjukkan bahwa sebagian besar siswa merasa pembelajaran online yang diikuti dari rumah cukup membosankan. Berdasarkan temuan ini yang menyebutkan masih adanya siswa yang merasa bosan dalam mengikuti pembelajaran online menunjukkan bahwa hasil penelitian ini juga mendukung penelitian sebelumnya yang menyebutkan bahwa pembelajaran online dapat membuat siswa merasa bosan selama mengikuti pembelajaran online (Anugrahana, 2020; Jannah et al., 2020; Noviati, 2020; Pujiasih, 2020; Purwanto et al., 2020; Ramanta \& Widayanti, 2020).

Selanjutnya dalam penelitian ini juga mampu menunjukkan kesiapan siswa terutama dalam kesiapan fasilitas yang dimiliki atau yang tersedia. Semakin siap fasilitas yang dimiliki/tersedia, maka semakin siap pelaksanaan pembelajaran online. Salah satu yang menentukan keberhasilan pembelajaran online adalah kesiapan infrastruktur, dalam hal ini adalah fasilitas internet (So \& Swatman, 2006). Hal yang sama juga diungkapkan bahwa ketersediaan jaringan internet dan infrastruktur lainnya harus tersedia secara baik untuk memperlacar kegiatan pembelajaran online (Kusmana, 2011). Berdasarkan hasil penelitian menunjukkan selama ini sudah banyak siswa yang mempunyai kesiapan fasilitas untuk mendukung kelancaran pelaksanaan pembelajaran online. Berdasarkan data yang ditampilkan dalam tabel 6 menunjukkan banyak siswa yang sangat siap 
dalam fasilitas yang dimiliki untuk mengikuti pembelajaran online. Siswa telah mempunyai $\mathrm{HP} /$ smartphone sekaligus tersedia jaringan internet yang cepat/stabil dan paket data internet yang mencukupi untuk mengikuti pembelajaran online. Kesiapan siswa dalam hal fasilitas ini menjadi sangat penting untuk kelancaran pembelajaran online.

Jaringan internet yang cepat dan stabil serta kuota atau paket data internet yang selalu mencukupi dapat menciptakan pelaksaaan pembelajaran online yang efektif. Hasil penelitian ini menunjukkan sebagian besar siswa tidak terkendala dengan masalah jaringan internet dan paket kuota data internet. Meskipun demikian berdasarkan tabel yang sama masih ditemui siswa yang belum siap/kurang siap dalam hal fasilitas yang tersedia/dimiliki untuk mendukung pembelajaran online yang diikuti. Ketidaksiapan dalam hal jaringan internet yang tidak stabil dan lambat serta paket data internet yang tidak mencukupi ketika tidak ada wifi gratis dapat menjadi masalah yang besar bagi siswa ketika mengikuti pembelajaran online.

Hasil penelitian ini mendukung penelitian sebelumnya yang menyebutkan bahwa mahasiswa dapat mengalami kesulitan untuk mengikuti pembelajaran onlie ketika tidak memiliki jaringan internet yang stabil dan paket data internet yang cukup (Setiaji \& Dinata, 2020). Hasil penelitian ini juga mendukung penelitian sebelumnya yang mengungkapkan masih ada siswa yang menghadapi masalah dalam jaringat internet yang lambat/tidak stabil maupun paket data internet yang terbatas ketika mengikuti pembelajaran online, sehingga dapat menghambat pelaksanaan pembelajaran online (Anugrahana, 2020; Engko \& Usmany, 2020; Firman \& Rahayu, 2020; Gayatri et al., 2021; Jannah et al., 2020; Ma et al., 2021; Noviati, 2020; Ramanta \& Widayanti, 2020; Rohmanu et al., 2020; Surani et al., 2020). Hasil penelitian ini juga mendukung temuan sebelumnya yang menyebutkan tantangan yang dihadapi dalam pembelajaran online adalah jaringan internet yang tidak stabil dan tambahan biaya untuk membeli kuota atau paket data internet (Bustomi, 2020; Pujiasih, 2020; Sadikin \& Hamidah, 2020).

Selanjutnya dalam penelitian ini juga mengungkapkan kelebihan dan kelemahan pembelajaran yang dilaksanakan secara online. Hasil penelitian penunjukkan banyak siswa yang menganggap bahwa dengan mengikuti pembelajaran secara online membuat siswa tidak perlu datang ke sekolah, pelaksanaannya fleksibel, dan hemat waktu dan biaya. Hasil ini mempunyai kesesuaian dengan data pada tabel 1 . Yang menunjukkan banyak siswa yang rumahnya jauh yang berjarak lebih dari 5 kilometer, sehingga siswa mendapatkan keuntungan dari pelaksanaan pembelajaran online. Melalui pembelajaran online siswa tidak perlu harus datang ke sekolah atau bahkan ketika berangkat ke sekolah tidak perlu terburu-buru, sehingga dapat menghemat waktu. Pembelajaran online juga sangat fleksibel karena dapat dilakukan dimana saja dan kapan saja selama ada jaringan internet, memiliki paket data internet ataupun wifi. Disamping itu siswa juga dapat menghemat biaya perjalanan seperti biaya untuk membeli BBM maupun tidak memerlukan sarana trasportasi karena tidak perlu datang ke sekolah. Dengan demikian hasil penelitian ini sejalan dengan beberapa penelitian yang mengungkapkan bahwa pembelajara online mempunyai beberapa kelebihan atau keunggulan seperti dapat menghemat biaya transportasi (Handayani, 2020; Pratiwi, 2020; Purwanto et al., 2020; Putri et al., 2020; Ramanta \& Widayanti, 2020; Setyorini, 2020), mempunyai fleksibilitas waktu dan tidak terikat dengan tempat belajar (Anderson \& Dron, 2011; Anugrahana, 2020; Firman \& Rahayu, 2020; Gunawan et al., 2020; Hamid, 2002; Handayani, 2020; Kirin et al., 2021; Nugroho, 2020; Ulfia, 2020; Wongjamnong et al., 2021).

Meskipun pembelajaran online mempunyai kelebihan dalam pelaksanaannya, namun pembelajaran online juga mempunyai kelemahan yang sering dijumpai yang dapat menghambat efektivitas pembelajaran. Kelemahan yang ada dapat menghambat jalannya pembelajaran online. Berdasarkan hasil penelitian menunjukkan bahwa sebagian besar siswa berpendapat dalam pembelajaran yang dilaksanakan secara online sangat tergantung pada jaringan internet dan ketersediaan kuota atau paket data internet. Ketika dua hal tersebut terganggu, maka proses pembelajaran yang diikuti siswa juga menjadi terganggu. Hasil penelitian ini sejalan dengan yang diungkapkan dalam beberapa penelitian sebelumnya yang menyebutkan permasalahan yang dihadapai dalam pembelajaran online adalah masalah jarigan internet yang tidak stabil/lambat, 
kuota internet yang cepat habis dan harganya relatif mahal (Anugrahana, 2020; Bustomi, 2020; Engko \& Usmany, 2020; Gayatri et al., 2021; Handayani, 2020; Jannah et al., 2020; Kirin et al., 2021; Ma et al., 2021; Mustopa \& Hidayat, 2020; Noviati, 2020; Pujiasih, 2020; Ramanta \& Widayanti, 2020; Rohmanu et al., 2020; Sadikin \& Hamidah, 2020; Surani et al., 2020; Ulfia, 2020). Kelemahan lain yang diungkapkan siswa selama mengikuti pembelajaran online adalah pemberian tugas. Siswa menganggap bahwa tugas yang diberikan oleh guru selama pembelajaran online lebih banyak. Seperti yang telah di jelaskan, hasil penelitian ini sesuai dengan hasil sebelumnya yang menunjukkan bahwa guru selama melaksanakan pembelajaran online memberikan lebih banyak tugas kepada siswa (Noviati, 2020; Pujiasih, 2020; Ramanta \& Widayanti, 2020; Ulfia, 2020).

Selanjutnya dalam penelitian ini juga menunjukkan bahwa di masa pandemi Covid-19, banyak siswa yang mengharapkan pembelajaran dapat dilaksanakan secara blended learning atau campuran antara pembelajaran online dengan pembelajaran tatap muka di sekolah. Pembelajaran ini dapat mengatasi hambatan atau kendala yang dihadapai dalam pembelajaran online. Seperti pada data yang telah dijelaskan sebelumnya menunjukkan masih ada siswa yang mempunyai ketidaksiapan dalam fasilitas seperti terkendala dalam jaringan dan keterbatasan kuota paket data internet. Disamping itu melalui pembelajaran campuran ini dapat mengantisipasi kekurangan lainnya dalam pembelajaran online seperti dapat meminimalisir ketidakmampuan siswa dalam memahami materi pelajaran, untuk mencegah kebosanan yang dialami siswa selama mengikuti pembelajaran, sekaligus menciptakan pembelajaran yang menarik dan menyenangkan. Banyaknya siswa yang menginginkan pembelajaran dapat dilakukan secara campuran (blended learning) mengindikasikan bahwa siswa sudah mulai dapat menyesuaikan dengan pembelajaran yang dilaksanakan secara online yang saat ini berlangsung. Meskipun berdasarkan data yang disajikan dalam penelitian ini juga menunjukkan masih adanya siswa yang menginginkan pembelajaran online dapat dilaksanakan secara penuh, maupun masih banyak siswa yang menginginkan pembelajaran dapat dilaksanakan secara tatap muka secara penuh di sekolah. Dengan demikian hasil temuan dalam penelitian ini mendukung dengan temuan penelitian sebelumnya yang menyebutkan siswa mengharapkan pembelajaran tidak sepenuhnya dilaksanakan secara online, tetapi mengharapkan pembelajaran dapat dilakukan secara tatap muka, atau paling tidak dengan cara menggambungkan (blended learning) pembelajaran tatap muka dengan pembelajaran online (Hariani \& Wastuti, 2020).

\section{PENUTUP}

Pandemi Covid-19 mampu memaksa pembelajaran yang awalnya dilaksanakan secara tatap muka menjadi pembelajaran yang dilaksanakan secara online. Pembelajaran online menjadi satusatunya solusi atas keberlangsungan pembelajaran di sekolah. Selama pembelajaran online berlangsung, guru menerapkan berbagai kegiatan belajar. Guru lebih banyak memberikan berbagai tugas selama pembelajaran online seperti memberikan kuis dan mengerjakan soal, disamping guru juga memberikan penjelasan terkait dengan materi pelajaran. Selama pembelajaran online, pola interaksi yang terjadi sudah berjalan dengan baik yang ditujukkan dengan adanya interaksi yang multi arah antara guru dengan siswa, meskipun sebagian guru dalam melaksanakan pembelajaran masih ada yang lebih dominan.

Pembelajaran online, masih banyak ditemukan siswa yang mengalami kesulitan untuk memahami materi pelajaran. Selain itu selama ini proses pembelajaran online yang diikuti dari rumah dirasa membosankan oleh sebagian besar siswa, karena proses pembelajaran online dilaksanakan secara penuh. Selanjutnya dalam mengikuti pembelajaran online diperlukan kesiapan siswa termasuk fasilitas. Keberadaan fasilitas yang dimiliki/tersedia seperti handpone/smartphone, tersedianya jaringan internet yang baik, ketersediaan kuota atau paket data interet, atau adanya wifi gratis menjadi sangat krusial bagi keberhasilan pelaksanaan pembelajaran online. Semakin siap fasilitas yang dimiliki maka pelaksanaan pembelajaran online dapat menjadi semakin baik, sehingga efektivitas pembelajaran dapat dicapai. Siswa sebagian besar sudah mempunyai kesiapan fasilitas untuk mengikuti pembelajaran online seperti jaringan internet yang 
stabil/cepat dan kuota atau paket data internet yang tersedia secara mencukupi, meskipun masih ada siswa yang belum mempunyai kesiapan fasilitas secara memadai untuk mengikuti pembelajaran online.

Pembelajaran online yang dilaksanakan selama pandemi Covid-19 mempunyai beberapa kelebihan, diataranya membuat siswa tidak perlu datang ke sekolah, mempunyai fleksibilitas dalam pelaksanaanya, dan dapat menghemat waktu dan biaya bagi siswa. Disamping mempunyai kelebihan, pembelajaran yang dilaksanakan secara online juga mempunyai kelemahan diantaranya sangat bergantung kepada jaringan internet dan bergantung kepada ketersediaan paket data internet untuk mengakses pembelajaran, dan pemberian tugas yang berlebihan dari guru yang dirasa memberatkan bagi siswa. Oleh karena itu siswa mengharapkan bahwa pembelajaran selama pandemi Covid-19 dapat dilaksanakan secara campuran (blended learning) yaitu menggabungkan pembelajaran online dengan pembelajaran tatap muka.

Disarankan kepada guru agar dapat menerapkan pembelajaran yang menarik dan menyenangkan bagi siswa dengan menggunakan berbagai metode pembelajaran seperti simulasi kegiatan yang dilakukan secara online, metode role playing secara online, metode problem solving, dan metode pembelajaran lainnya yang berpusat pada siswa, sehingga siswa tidak mengalami kebosanan ketika mengikuti pembelajaran online. Selain itu meskipun siswa sudah mendapatkan bantuan paket data internet dari pemerintah, tetapi sekolah secara mandiri perlu memberikan bantuan paket data internet khususnya kepada siswa yang kurang mampu agar proses pembelajaran dapat diikuti oleh semua siswa dengan baik dan lancar.

\section{REFERENSI}

Ally, M. (2008). Foundations of Educational Theory for Online Learning. In T. Anderson (Ed.), The Theory and Practice of Online Learning (pp. 15-44). AU Press.

Alqurashi, E. (2018). Predicting Student Satisfaction and Perceived Learning Within Online Learning Environments. Distance Education, 40(1), 133-148. https://doi.org/10.1080/01587919.2018.1553562

Amri, F., Djatmika, E. T., Wahyono, H., \& Widjaja, S. U. M. (2020). The Effect of Using Simulation on Developing Students' Character Education in Learning Economics. 13(4), 375-392. https://doi.org/10.29333/iji.2020.13424a

Anderson, T. (2008). Towards a Theory of Online Learning. In T. Anderson (Ed.), The Theory and Practice of Online Learning (2nd ed, pp. 45-74). AU Press.

Anderson, T., \& Dron, J. (2011). Three Generations of Distance Education Pedagogy. International Review of Research in Open and Distributed Learning, 12(3), 80-97. https://doi.org/10.19173/irrodl.v12i3.890

Anugrahana, A. (2020). Hambatan, Solusi dan Harapan: Pembelajaran Daring Selama Masa Pandemi Covid-19 oleh Guru Sekolah Dasar. Scholaria: Jurnal Pendidikan dan Kebudayaan, 10(3), 282-289. https://doi.org/10.24246/j.js.2020.v10.i3.p282-289

Balula, A., \& Moreira, A. (2014). Evaluation of Online Higher Education: Learning, Interaction and Technology. Springer International Publishing. https://doi.org/10.1007/978-3-31905425-4

Barbour, M. K. (2017). K-12 Online Learning and School Choice: Growth and Expansion in the Absence of Evidence. In R. A. Fox \& N. K. Buchanan (Eds.), The Wiley Handbook of School Choice (pp. 421-440). John Wiley \& Sons, Inc.

Borup, J., \& Kennedy, K. (2017). The Case for K-12 Online Learning. In R. A. Fox \& N. K. Buchanan (Eds.), The Wiley Handbook of School Choice (pp. 403-420). John Wiley \& Sons, Inc. https://doi.org/10.1002/9781119082361.ch28

Bustomi, A. (2020). Implikasi Covid 19 terhadap Pembelajaran di Perguruan Tinggi. Jurnal Tawadhu, 4(1), 1007-1017.

Chen, P.-S. D., Lambert, A. D., \& Guidry, K. R. (2010). Engaging Online Learners: The Impact of Web-Based Learning Technology on College Student Engagement. Computers \& Education, 54(4), 1222-1232. https://doi.org/10.1016/j.compedu.2009.11.008 
Cigdem, H., \& Yildirim, O. (2014). Effects of Students' Characteristics on Online Learning Readiness: A Vocational College Example. Turkish Online Journal of Distance Education, 15(3), 80-93. https://doi.org/10.17718/tojde.69439

Dewstow, R., \& Wright, N. (2005). Secondary School Students, Online Learning, and External Support in New Zealand. Interdisciplinary Journal of Practice, Theory, and Applied Research, 22(1-2), 111-122. https://doi.org/10.1300/J025v22n01_10

Engko, C., \& Usmany, P. (2020). Dampak Pandemi Covid-19 terhadap Proses Pembelajaran Online: Studi Eksploratif pada Mahasiswa Jurusan Akuntansi Fakultas Ekonomi dan Bisnis Universitas Pattimura. Jurnal Akuntansi, 6(1), 23-38.

Fahy, P. J. (2008). Characteristics of Interactive Online Learning Media. In T. Anderson (Ed.), The Theory and Practice of Online Learning (pp. 167-199). AU Press.

Figlio, D., Rush, M., \& Li, Y. (2013). Is it Live or is it Internet? Experimental Estimates of the Effects of Online Instruction on Student Learning. Journal of Labor Economics, 31(4), 763 784.

Firman, \& Rahayu, S. (2020). Pembelajaran Online di Tengah Pandemi Covid-19. Indonesian Journal of Educational Science (IJES), 2(2), 81-89. https://doi.org/10.31605/ijes.v2i2.659

Gayatri, A. M., Adi, T. M., \& Muzdalifah. (2021). Kelemahan Media Internet dalam Pelaksanaan $\begin{array}{llll}\text { Pembelajaran } \quad \text { saat } \quad \text { Pandemi. } & \text { INTELEKTIUM, }\end{array}$ https://doi.org/10.37010/int.v2i1.280

Gunawan, Suranti, N. M., \& Fhatoroni. (2020). Variations of Models and Learning Platforms for Prospective Teachers During the COVID-19 Pandemic Period. Journal of Teacher Education, 1(2), 61-70.

Hamid, A. A. (2002). E-Learning, is it the ' $\mathrm{E}$ ' or the Learning that Matters?. Internet and Higher Education, 4, 311-316. https://doi.org/10.1080/13523260.2020.1761749

Handayani, L. (2020). Keuntungan, Kendala dan Solusi Pembelajaran Online Selama Pandemi Covid-19: Studi Ekploratif di SMPN 3 Bae Kudus. Journal Industrial Engineering \& Management Research, 1(2), 15-23. https://doi.org/10.7777/jiemar.v1i2.36

Harasim, L. (2012). Learning Theory and Online Technologies. Routledge.

Hariani, P. P., \& Wastuti, S. N. Y. (2020). Pemanfaatan E-Learning pada Pembelajaran Jarak Jauh di Masa Pandemi Covid-19. Biblio Couns : Jurnal Kajian Konseling dan Pendidikan, 3(2), 41-49. https://doi.org/10.30596/bibliocouns.v3i2.4656

Hurlbut, A. R. (2018). Online vs. Traditional Learning in Teacher Education: A Comparison of Student Progress. American Journal of Distance Education, 32(4), 248-266. https://doi.org/10.1080/08923647.2018.1509265

Jannah, M., Bustamam, N., \& Yahya, M. (2020). Kesiapan Diri Mahasiswa dalam Menghadapi Perkuliahan Daring. Jurnal Ilmiah Mahasiswa Bimbingan dan Konseling, 5(3), 13-18.

Joosten, T., \& Cusatis, R. (2020). Online Learning Readiness. American Journal of Distance Education, 34(3), 180-193. https://doi.org/10.1080/08923647.2020.1726167

Kharisma, N. N., Roesminingsih, M. V., \& Suhanadji. (2020). Gambaran Kebutuhan Pembelajaran Daring PKBM Budi Utama Surabaya pada Masa Pandemi Covid-19. Jurnal Pendidikan Nonformal, 15(1), 38-44. https://doi.org/10.17977/um041v15i1p38-45

Kirin, A., Isma'il, F. H., Masruri, M., Marpuah, S., \& Mohammad, C. A. (2021). Pengajaran dan Pembelajaran Metode Face to Face dan PJJ Online: Perbandingan dan Impak terhadap Students UTHM Johor Malaysia Semasa Pandemi Covid-19. Jurnal Studi Guru Dan Pembelajaran, 4(1), 206-217. https://doi.org/10.30605/jsgp.4.1.2021.534

Kongrith, K., \& Maddux, C. D. (2005). Online Learning as a Demonstration of Type II Technology. Computers in the Schools, 22(1-2), 97-110. https://doi.org/10.1300/J025v22n01_09

Kusmana, A. (2011). E-Learning dalam Pembelajaran. Lentera Pendidikan : Jurnal Ilmu Tarbiyah dan Keguruan, 14(1), 35-51. https://doi.org/10.24252/lp.2011v14n1a3

Ma, S. H. G., Parera, H. R., \& Amrin, S. (2021). Kesiapan Guru Ekonomi dalam Menghadapi Online Learning di Kota Ende. Cetta: Jurnal Ilmu Pendidikan, 4(1), 33-46. 
Mahnun, N. (2018). Implementasi Pembelajaran Online dan Optimalisasi Pengelolaan Pembelajaran Berbasis Online di Perguruan Tinggi Islam dalam Mewujudkan World Class University. Indonesian Journal Of Islamic Educational Management, 1(1), 29-36. https://doi.org/10.24014/ijiem.v1i1.5240

Markova, T., Glazkova, I., \& Zaborova, E. (2017). Quality Issues of Online Distance Learning. Procedia - Social and Behavioral Sciences, 237, 685-691. https://doi.org/10.1016/j.sbspro.2017.02.043

Moore, J. L., Dickson-Deane, C., \& Galyen, K. (2011). E-Learning, Online Learning, and Distance Learning Environments: Are they the Same? The Internet and Higher Education, 14(2), 129-135. https://doi.org/10.1016/j.iheduc.2010.10.001

Murphy, M. P. A. (2020). COVID-19 and Emergency Elearning: Consequences of the Securitization of Higher Education for Post-Pandemic Pedagogy. Contemporary Security Policy, 41(3), 1-14. https://doi.org/10.1080/13523260.2020.1761749

Mustopa, A. J., \& Hidayat, D. (2020). Pengalaman Mahasiswa Saat Kelas Online Menggunakan Aplikasi Zoom Cloud Meeting Selama Covid-19. Jurnal Digital Media \& Relationship, 2(2), 75-84.

Nord, D. (2011). Online Learning Programs: Evaluation's Challenging Future. In S. Mathison (Ed.), Really New Directions in Evaluation: Young Evaluators' Perspectives (pp. 129-134). New Directions for Evaluation. https://onlinelibrary.wiley.com/doi/10.1002/ev.390

Noviati, W. (2020). Kesulitan Pembelajaran Online Mahasiswa Pendidikan Biologi di Tengah Pandemi Covid19. Jurnal Pendidikan MIPA, 10(1), 7-11. https://doi.org/10.37630/jpm.v10i1.258

Nugroho, G. B. (2020). Peran Guru Bimbingan dan Konseling dalam Pendampingan Belajar Siswa Selama Pembelajaran Online. Jurnal Psiko-Edukasi, 18(1), 73-83.

Nuriansyah, F. (2020). Efektifitas Penggunaan Media Online dalam Meningkatkan Hasil Belajar pada Mahasiswa Pendidikan Ekonomi saat Awal Pandemi Covid-19. Jurnal Pendididikan Ekonomi Indonesia, 1(2), 61-65.

Pratiwi, E. W. (2020). Dampak Covid-19 terhadap Kegiatan Pembelajaran Online di Perguruan Tinggi Kristen di Indonesia. Perspektif Ilmu Pendidikan, 34(1), 1-8. https://doi.org/10.21009/PIP.341.1

Pujiasih, E. (2020). Membangun Generasi Emas dengan Variasi Pembelajaran Online Di Masa Pandemi Covid-19. Ideguru: Jurnal Karya Ilmiah Guru, 5(1), 42-48. https://doi.org/10.51169/ideguru.v5i1.136

Purwanto, A., Pramono, R., Asbari, M., Santoso, P. B., Mayesti, L., Hyun, C. C., \& Putri, R. S. (2020). Studi Eksploratif Dampak Pandemi COVID-19 terhadap Proses Pembelajaran Online di Sekolah Dasar. EduPsyCouns: Journal of Education, Psychology and Counseling, 2(1), 1-12.

Putri, R. S., Purwanto, A., Pramono, R., Asbari, M., Wijayanti, L. M., \& Hyun, C. C. (2020). Impact of the COVID-19 Pandemic on Online Home Learning: An Explorative Study of Primary Schools in Indonesia. International Journal of Advanced Science and Technology, 29(5), 4809-4818.

Rabe-Hemp, C., Woollen, S., \& Humiston, G. S. (2009). A Comparative Analysis of Student Engagement, Learning and Satisfaction in Lecture Hall and Online Learning Settings. The Quarterly Review of Distance Education, 10, 207-218.

Ramanta, D., \& Widayanti, F. D. (2020). Pembelajaran Daring di Sekolah Menengah Kejuruan Putra Indonesia Malang pada Masa Pandemi COVID-19. Mengukuhkan Eksistensi Peran BK Pasca Pandemi Covid-19 di Berbagai Setting Pendidikan, 61-67. http://conference.um.ac.id/index.php/bk2/article/view/81

Rohmanu, A., Muafiah, E., Hakim, A. R., \& Damayanti, V. V. W. (2020). Kesiapan, Kompleksitas dan Harapan Pembelajaran Jarak Jauh: Perspektif Mahasiswa IAIN Ponorogo. Al-Tadzkiyyah: Jurnal Pendidikan Islam, 11(2), 221-241. https://doi.org/10.24042/atjpi.v11i2.7019 
Sadikin, A., \& Hamidah, A. (2020). Pembelajaran Daring di Tengah Wabah Covid-19. BIODIK, 6(2), 109-119. https://doi.org/10.22437/bio.v6i2.9759

Setiaji, B., \& Dinata, P. A. C. (2020). Analisis Kesiapan Mahasiswa Jurusan Pendidikan Fisika Menggunakan E-Learning dalam Situasi Pandemi Covid-19. Jurnal Inovasi Pendidikan IPA, 6(1), 59-70. https://doi.org/10.21831/jipi.v6i1.31562

Setyorini, I. (2020). Pandemi COVID-19 dan Online Learning: Apakah Berpengaruh terhadap Proses Pembelajaran pada Kurikulum 13?. Journal of Industrial Engineering \& Management Research, 1(1), 95-102. https://doi.org/10.7777/jiemar.v1i1.31

So, T., \& Swatman, P. M. C. (2006). E-Learning Readiness of Hong Kong Teachers. University of South Australia.

Surani, D., Kusuma, J. W., \& Kusumawati, N. (2020). Platform Online dalam Perkuliahan pada Masa Pandemi Covid-19. Jurnal Pendidikan: Teori, Penelitian, dan Pengembangan, 5(9), 1338-1349. https://doi.org/10.17977/jptpp.v5i9.14057

Ulfia, N. (2020). Pembelajaran Daring di Masa Pandemi Covid-19: Refleksi Para Siswa. Prosiding Nasional Pendidikan: LPPM IKIP PGRI Bojonegoro. Prosiding Nasional Pendidikan: LPPM IKIP PGRI Bojonegoro, 1, 731-734.

Wei, H.-C., \& Chou, C. (2020). Online Learning Performance and Satisfaction: Do Perceptions and Readiness Matter? Distance Education, 41(1), 48-69. https://doi.org/10.1080/01587919.2020.1724768

Wongjamnong, C., Muangou, C., \& Nuangchalerm, P. (2021). Opinions of Students and Teachers in Primary School towards Online Learning during COVID-19 Outbreak. Pedagogi: Jurnal Ilmu Pendidikan, 21(1), 30-35. https://doi.org/10.24036/pedagogi.v21i1.1006 